\title{
Impact of selected thermal and flow parameters on flow boiling heat transfer in a minichannel
}

\author{
Kinga Strąk $^{1 *}$ and Magdalena Piasecka ${ }^{2}$ \\ ${ }^{1,2}$ Faculty of Mechatronics and Mechanical Engineering, Kielce University of Technology, Al. 1000-lecia P.P. 7, 25-314 Kielce, Poland
}

\begin{abstract}
This paper reports an impact of selected thermal and flow parameters i.e., mass flux and inlet pressure on flow boiling heat transfer in a minichannel. Research was carried out on the experimental set up with the test section fitted with a single, rectangular and vertically oriented minichannel $1.7 \mathrm{~mm}$ deep. Infrared thermography was used to determine changes in the temperature on the outer side of the heated minichannel wall in the central part of the minichannel. The heated element for HFE-649 flowing in the minichannel was a thin alloy plate, made of Haynes-230. Local values of heat transfer coefficient for stationary state conditions were calculated using a simple one-dimensional method. Analysis of the results was based on experimental series obtained for the same heat flux, various mass fluxes and average inlet pressures. The experimental results are presented as the relationship between the heat transfer coefficient and the distance along the minichannel length and boiling curves. The highest local heat transfer coefficients were obtained for the lower average inlet pressure and for the highest mass flux at lower heat flux.
\end{abstract}

\section{Introduction}

Small confined spaces such as minichannels are an attractive option for two-phase cooling applications. Small enough to generate large heat fluxes, minichannels are capable of removing large amounts of heat, presenting fewer maintenance issues than true microscale channels. Adopting two-phase minichannel cooling systems to next generation high-flux heat exchangers is an important consideration for industries. Studies are being run to improve fundamental understanding of phase change phenomena (flow and pool boiling or condensation in mini spaces).

Research reported in the literature confirms the importance of different flow and thermal parameters or position of test sections in the flow and pool boiling heat transfer models for minichannels.

Konishi et al. [1] studied flow boiling critical heat flux (CHF) in a rectangular channel at different mass velocities, inlet qualities and orientations relative to Earth's gravity. They found that the influence of orientation on CHF was significant at low mass velocities and insignificant at high mass velocities, especially for high inlet qualities. The CHF sensitivity to orientation was lower for upflow orientations and upward-facing heated wall positions and higher for downward flow and downward-facing wall positions.

Kanizawa et al. [2] reported their heat transfer coefficient experiment during flow boiling of different refrigerants inside small diameter tubes at mass velocities from 49 to $2200 \mathrm{~kg} \cdot \mathrm{m}^{-2} \mathrm{~s}^{-1}$ and heat fluxes up to $185 \mathrm{~kW} \cdot \mathrm{m}^{-2}$. The data were analysed and the influence of experimental parameters (mass velocity, tube diameter, heat flux, refrigerant type and saturation temperature) on the heat transfer coefficient and dryout vapor quality was identified. The heat transfer coefficient increased with increasing mass velocity, heat flux and saturation temperature, and decreased with tube diameter. Moreover, the dryout vapor quality decreased with increasing mass velocity and vapor specific volume.

Bohdal et al. [3] presented the results of experimental heat transfer during condensation of a single component refrigerant R134a and zeotropic mixtures R404A, $\mathrm{R} 407 \mathrm{C}$ and R410A in tube minichannels. The heat transfer coefficient was dependent on thermal parameters of the condensation process (including saturation temperature), inner diameter of the tubular minichannel, mass flux and vapor quality.

The Kielce University of Technology has conducted a series of studies of flow boiling heat transfer with different refrigerants [4-6] flowing along minichannels with enhanced heated plates $[4,7-14]$ at various orientations $[4,15,16]$. The use of enhanced surfaces produced in thermal processes is known to intensify the heat transfer process as shown in [7,17-21] Such surfaces are applied also in pool boiling heat transfer [22-26]. Studies on heat transfer in confined spaces as face seals were described in [27-29].

\section{Experiment stand}

The main systems of the experimental setup presented in Fig. 1. The test section with vertical minichannels is the 
main element of flow loop comprises, described in detail in $[4,7,9,12,14,30-32]$

Temperature changes on one side of the plate were measured with an E60 FLIR infrared camera (Fig. 1, (13)) of accuracy: $\pm 1{ }^{\circ} \mathrm{C}$ or $\pm 1 \%$, temperature range: $0 \div 120^{\circ} \mathrm{C}$ [33]. The plate surface was coated with black paint (to obtain emissivity of 0.97). Narrow micanite panels placed on both sides of the plate prevented its deformation. The side in contact with the fluid was observed through a glass panel. Type K thermocouples and pressure meters (8) were mounted at the minichannel inlet and outlet.

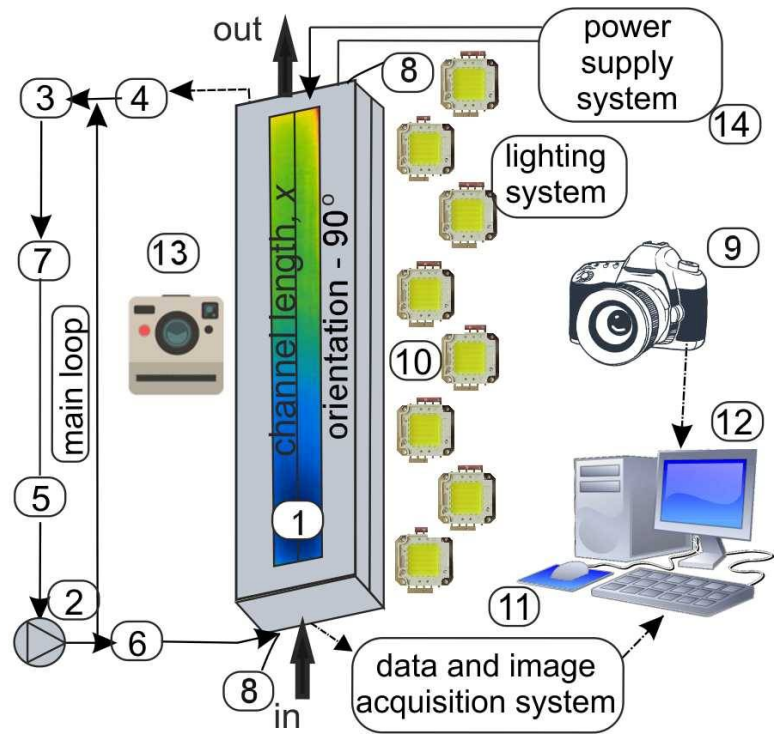

Fig. 1. The schematic of the main systems of the experimental setup, 1-a test section with a minichannel, 2-a gear pump, 3-a pressure sensor, 4-a tube-type heat exchanger, 5-a filter, 6-a mass flowmeter, 7-a deaerator, 8-a pressure meter, 9-a fast camera, 10-a high power LEDs (400 W), 11-a data acquisition station, 12-a pc computer, 13-an infrared camera, 14-a power supply system.

Figure 2 shows a cross-sectional view of the test section. The apparatus is a vertical rectangular channel, $16 \mathrm{~mm}$ wide, $180 \mathrm{~mm}$ long and $1.7 \mathrm{~mm}$ deep. The working fluid is HFE-649. The channel height is determined by the thickness of the Teflon gasket external to the o-ring. The plate surface is a $0.45 \mathrm{~mm}$ Haynes- 230 alloy with factory complete surfaces. It is held against the o-rings and Teflon gasket by a frame composed of a smaller glass plate which, in turn, is enclosed in the duralumin plate.

During the experimental series, electric power supplied to the heated plate was gradually increased, as was the heat flux transferred to the fluid in the minichannel, thus initiating nucleate boiling and enhancing heat transfer. The first region after the boiling onset was the subcooled boiling region - the liquid became superheated only in the vicinity of the heated surface; it was highly subcooled in the core of the flow.

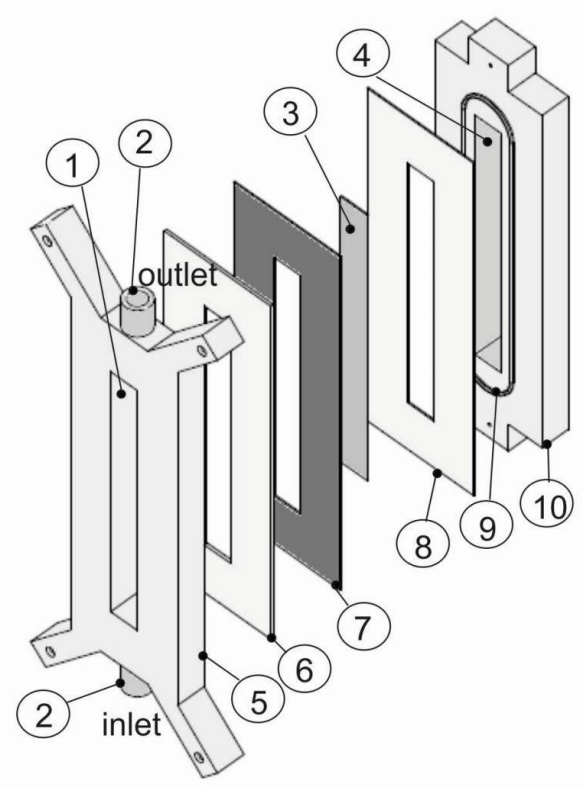

Fig. 2. Cross-sectional view of the test section, 1-a temperature measurement detection, 2-a thermocouple, 3-an enhanced heated plate, 4-a glass panel, 5-a front cover, 6, 8-a Teflon plate, 7-a graphite plate, 9-an o-ring, 10-a channel body.

\section{Calculations}

Previous studies of the authors examined other methods for determining the local heat transfer coefficient in two-dimensional approaches, using the Trefftz or Beck methods obtained from solving the inverse problem $[4,5,9,12,34-38]$.

In this paper, local heat transfer coefficients were determined using the one-dimensional method $[12,14,31,32,39]$. Heat flow direction perpendicular to the direction of the fluid flow in the minichannel was taken into account. In the subcooled boiling region, local coefficients were determined from the following equation

$$
\alpha(x)=q_{w} /\left(T_{P}(x, \delta)-T_{f}(x)-q_{w} \cdot \frac{\delta_{P}}{\lambda_{P}}\right)
$$

where: $x$ - distance from the minichannel inlet along the direction of the flow, $T_{p}(x)$ - plate temperature, measured by using infrared camera, $T_{f}(x)$ - fluid temperature calculated from the assumption of the linear distribution of the fluid temperature along the minichannel, $\lambda_{P}$ thermal conductivity of the heated plate, $\delta_{P}$ - thickness of the heated plate, $q_{w}$ - density of the heat flux transferred from the heated plate to the fluid was defined as:

$$
q_{w}=(I \cdot \Delta U / A)
$$

where: $I$ - current, $\Delta T$ - voltage drop, $A$ - surface area of the heated plate.

\section{Results and discussion}

The experimental results pertain to the steady state (stationary condition). The analysis includes the data from the experiments performed for:

- various average inlet pressures at four heat fluxes $\left(43,50,57\right.$ and $\left.64 \mathrm{~kW} \cdot \mathrm{m}^{-2}\right)$ supplied to the enhanced 
heated plate modified by vibration assisted laser surface texturing $(R a=1.364, S a=1.981)$;

- three different mass fluxes $\left(G=209 \mathrm{~kg} \cdot \mathrm{m}^{-2} \mathrm{~s}^{-1}\right.$, $G=414 \mathrm{~kg} \cdot \mathrm{m}^{-2} \mathrm{~s}^{-1}$ and $\left.G=616 \mathrm{~kg} \cdot \mathrm{m}^{-2} \mathrm{~s}^{-1}\right)$ at four heat fluxes $\left(29,40,55\right.$ and $\left.71 \mathrm{~kW} \cdot \mathrm{m}^{-2}\right)$ for the smooth heated plate $(R a=0.1752, S a=0.3455)$.

The results are presented graphically as:

- the heat transfer coefficient versus the distance from the minichannel inlet at the the subcooled boiling region, at four heat fluxes, for:

- two various inlet pressures (Fig. 3),

- three mass fluxes (Fig. 4),

- boiling curves generated for selected distances from the minichannel inlet $(0.045 \mathrm{~m}, 0.09 \mathrm{~m}$ and $0.135 \mathrm{~m})$, for:

- two average inlet pressures (Fig. 5),

- three mass fluxes (Fig. 6).

The experimental parameters of tested series are presented in Table 2.

Table 2. Experimental parameters of tested series.

\begin{tabular}{|c|c|c|c|}
\hline \multicolumn{4}{|c|}{ Tested series } \\
\hline $\begin{array}{c}\text { Heat flux } \\
\text { density } \\
q_{w} \\
\left(\mathrm{~kW} \cdot \mathrm{m}^{-2}\right)\end{array}$ & $\begin{array}{c}\text { Mass flux } \\
G \\
\left(\mathrm{~kg} \cdot \mathrm{m}^{-2} \mathrm{~s}^{-1}\right)\end{array}$ & $\begin{array}{c}\text { Inlet } \\
\text { pressure } \\
p_{\text {in }} \\
(\mathrm{kPa})\end{array}$ & $\begin{array}{c}\text { Inlet liquid } \\
\text { sub- } \\
\text { cooling } \\
\Delta T_{\text {sub }}(\mathrm{K})\end{array}$ \\
\hline \multirow{2}{*}{43} & \multirow{8}{*}{400} & 157 & \multirow{2}{*}{46} \\
\hline & & 200 & \\
\hline \multirow{2}{*}{50} & & 160 & \multirow{2}{*}{49} \\
\hline & & 257 & \\
\hline \multirow{2}{*}{57} & & 165 & \multirow{2}{*}{53} \\
\hline & & 322 & \\
\hline \multirow{2}{*}{64} & & 185 & \multirow{2}{*}{56} \\
\hline & & 370 & \\
\hline 29 & \multirow{4}{*}{$\begin{array}{l}209 \\
414 \\
616\end{array}$} & 137 & 42 \\
\hline 40 & & 152 & 45 \\
\hline 55 & & 172 & 49 \\
\hline 71 & & 207 & 54 \\
\hline
\end{tabular}

In the subcooled boiling region (Figs. 3-4), heat transfer coefficients were relatively low in comparison to those at the saturated boiling region $[4,40]$. The local heat transfer coefficient values increased with the distance from the minichannel inlet.

The highest local heat transfer coefficients were recorded for lower average inlet pressure at all heat fluxes analysed (Fig. 3). The highest local heat transfer coefficients were observed at the highest heat flux of $64 \mathrm{~kW} \cdot \mathrm{m}^{-2}$ in the outlet section of the minichannel $\left(\max 4.5 \mathrm{~kW} \cdot \mathrm{m}^{-2} \mathrm{~K}^{-1}\right.$, Fig. $\left.3 \mathrm{~d}\right)$. The lower heat transfer coefficient values $\left(\max 3.5 \mathrm{~kW} \cdot \mathrm{m}^{-2} \mathrm{~K}^{-1}\right)$ were obtained at high pressures and at higher heat fluxes (Fig. 3 b-d). The similar distribution of coefficient values was achieved for the lowest heat flux near the outlet of the minichannel (Fig. 3a). The discrepancies in the values of the coefficient for low and high pressures increased with increasing heat flux. It is therefore evident that the inlet pressure affects the coefficient value. Lower pressure increases the local heat transfer coefficient and makes heat transfer more effective.
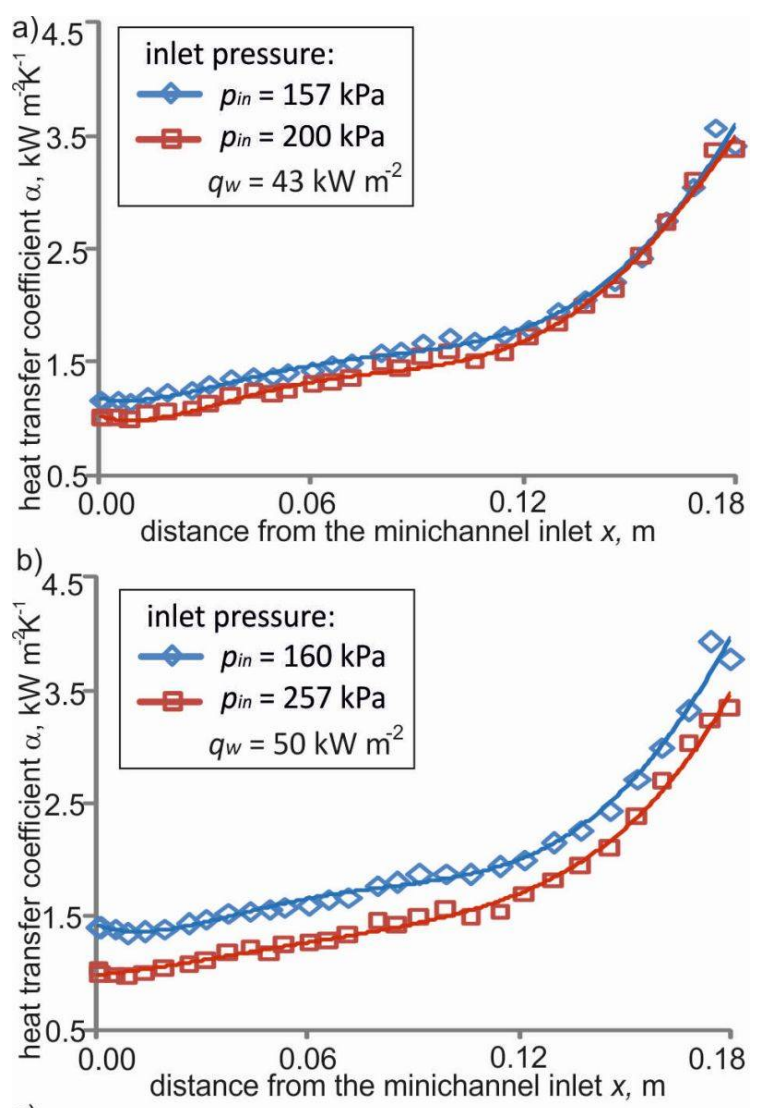

c)
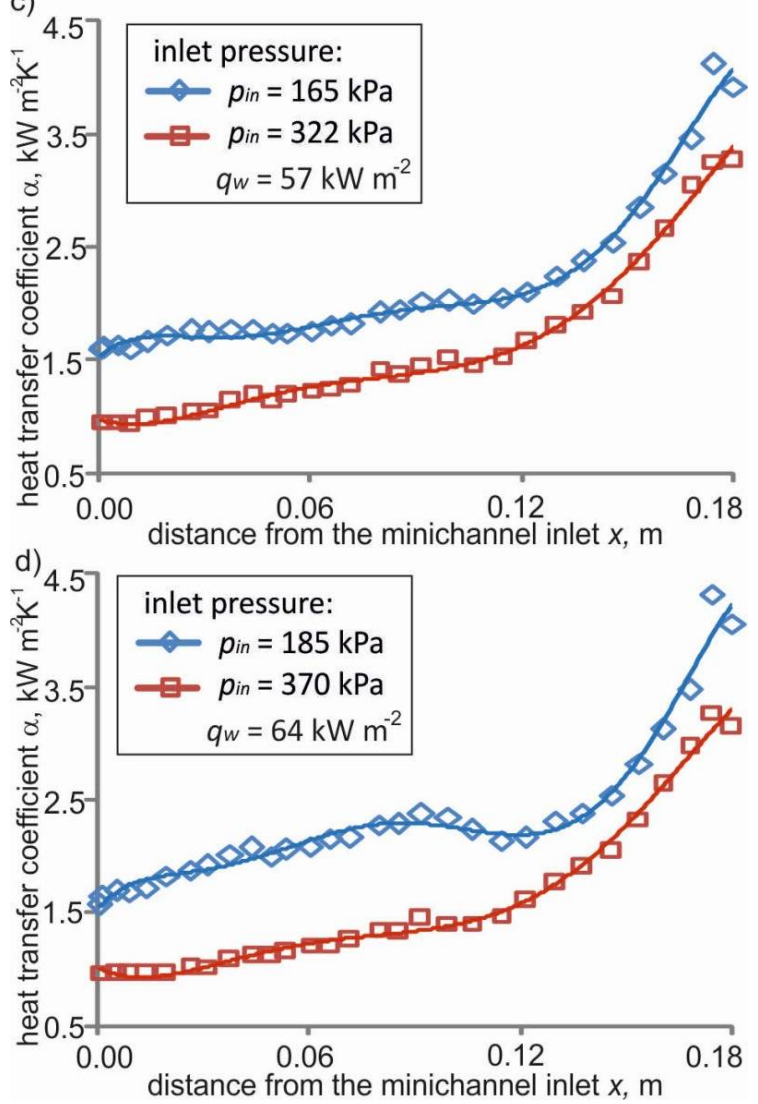

Fig. 3. Heat transfer coefficient vs. distance from the minichannel length obtained for the subcooled boiling region at various inlet pressures. 


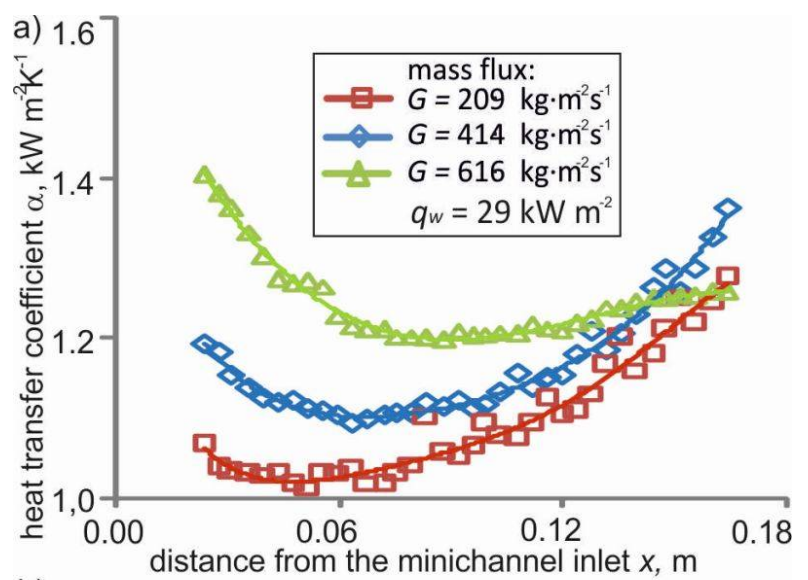

Analysis of the experimental results for different mass fluxes indicates that:

- the highest heat transfer coefficient was observed at the highest mass flux $\left(G=616 \mathrm{~kg} \cdot \mathrm{m}^{-2} \mathrm{~s}^{-1}\right)$ and lower heat fluxes (29 and $40 \mathrm{~kW} \cdot \mathrm{m}^{-2}$, Fig. $\left.4 \mathrm{a}, \mathrm{b}\right)$,

- at the lowest mass flux $\left(G=209 \mathrm{~kg} \cdot \mathrm{m}^{-2} \mathrm{~s}^{-1}\right)$, the highest local heat transfer coefficients were obtained at higher heat fluxes (55 and $71 \mathrm{~kW} \cdot \mathrm{m}^{-2}$, Figs. 4c,d) in the outlet section of the minichannel.

Similar dependencies were observed by Strąk et al. in [5], where markedly higher local heat transfer coefficients were also observed at lower mass flux in the saturated boiling region.

a)
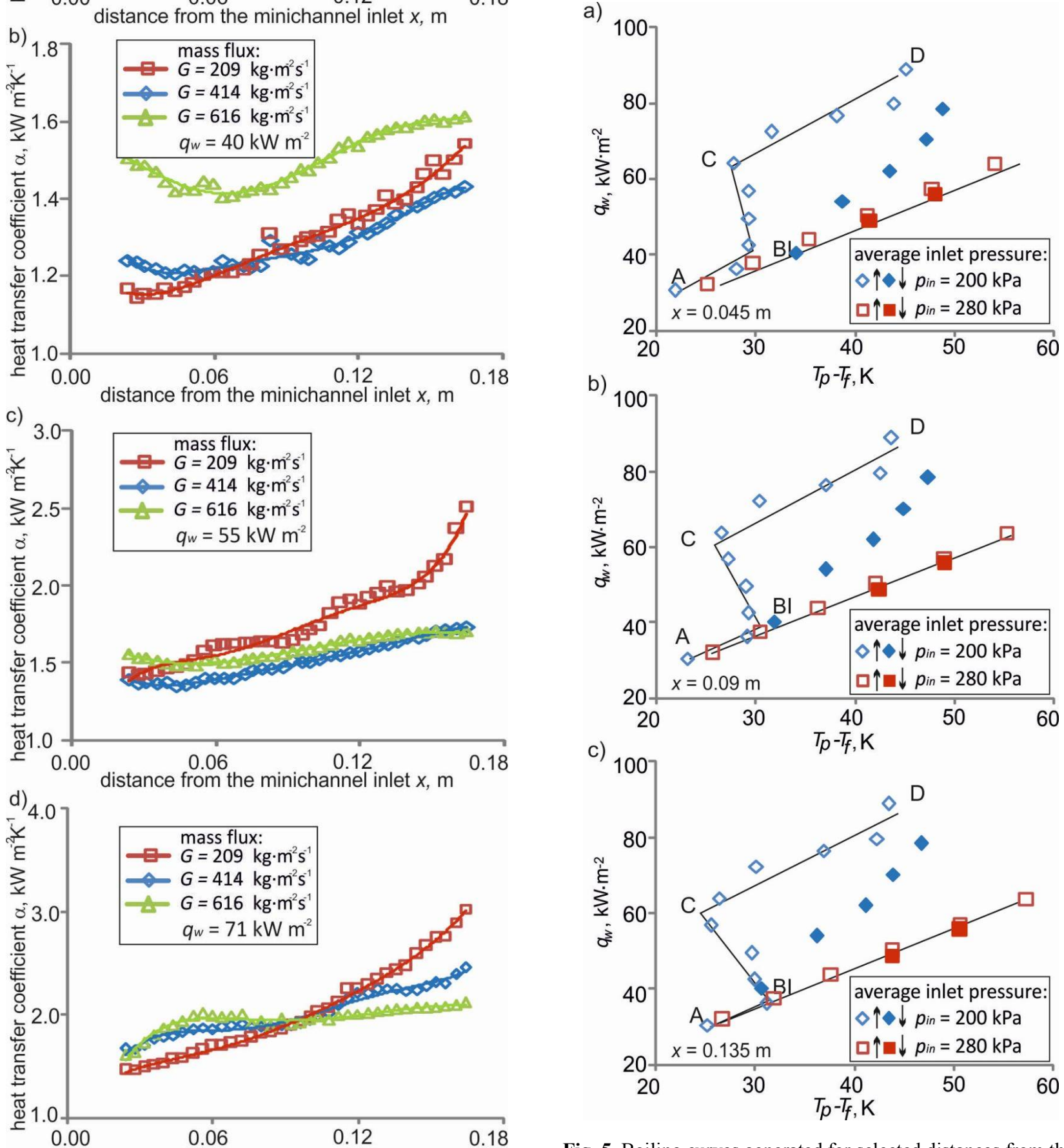

Fig. 5. Boiling curves generated for selected distances from the minichannel inlet $(0.045 \mathrm{~m}, 0.09 \mathrm{~m}$ and $0.135 \mathrm{~m})$ for two average inlet pressures, constructed as: $q_{w}$ vs. $T_{p}-T_{f}, T_{p}$ - heated plate temperature, $T_{f}$ - bulk fluid temperature.

minichannel length obtained for the subcooled boiling region at three mass fluxes. 
The boiling curves in Figs. 5 and 6 were plotted for two average inlet pressure values (Fig. 5) and three mass fluxes (Fig. 6) while increasing (empty markers) and decreasing (filled markers) the heat flux. The curves represent the heat flux density against the temperature difference $T_{p}-T_{f}$ for three selected distances from the inlet: $0.045 \mathrm{~m}, 0.09 \mathrm{~m}$ and $0.135 \mathrm{~m}$.

a)
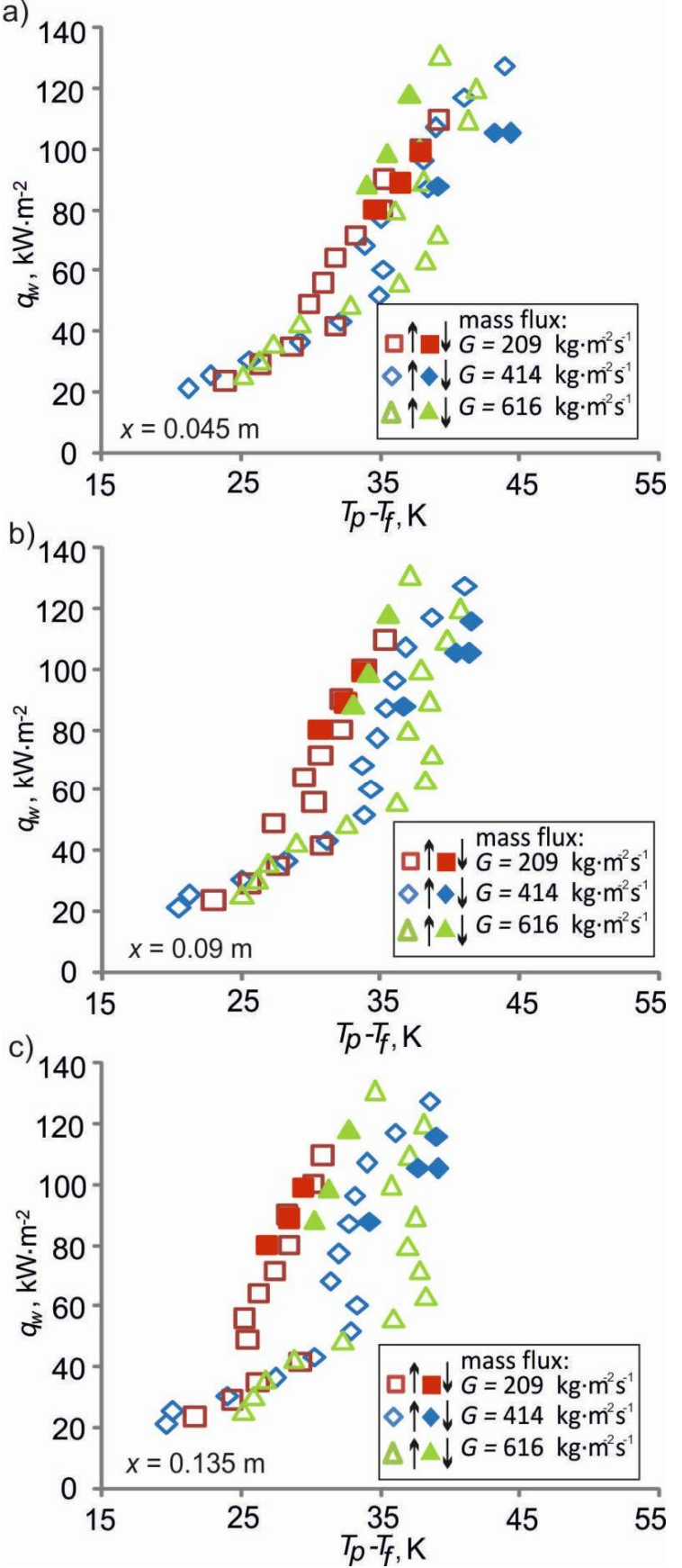

Fig. 6. Boiling curves generated for selected distances from the minichannel inlet $(0.045 \mathrm{~m}, 0.09 \mathrm{~m}$ and $0.135 \mathrm{~m})$ for three mass fluxes, constructed similarly as in Fig. 5.

All the curves had a typical shape except the ones constructed for higher average inlet pressure (Fig. 5), being near linear. At the lower pressure, nucleation hysteresis occurred due to a spontaneous nucleation at boiling incipience, which caused a drop in the temperature of the heated surface [41]. Nucleation hysteresis is characteristic of highly wetting dielectric fluids (e.g. refrigerants). The highest scatter and variability across the experimental data of the test series were observed at the lower average inlet pressure (Fig. 5) and the higher mass flux (Fig. 6).

\section{Conclusions}

This paper presents impact of mass flux and inlet pressure carried out on the experimental set up for HFE-649 flow boiling heat transfer in a vertical minichannel $1.7 \mathrm{~mm}$ deep, $16 \mathrm{~mm}$ wide and $180 \mathrm{~mm}$ long. The heated element for working fluid flowing in a minichannel was designated as a thin Haynes-230 alloy plate. Infrared thermography was used to measure the temperature of the outer plate surface.

The local values of the heat transfer coefficient were calculated using one-dimensional method in the subcooled boiling region, at four heat fluxes supplied to the plate. The experimental results were presented as the relationship between the heat transfer coefficient vs. the distance along the minichannel length and boiling curves.

The highest local heat transfer coefficients were obtained for the lower average inlet pressure at all heat fluxes under analysis. As for the mass flux, the highest local heat transfer coefficients were recorded for the highest mass flux at lower heat flux. At the lowest mass flux, the highest local heat transfer coefficients were obtained at higher heat fluxes.

The boiling curves were plotted as the heat flux density against the temperature difference $T_{p}-T_{f}$ for three selected distances from the minichannel inlet, under increasing and decreasing heat fluxes. All the curves were typical in shape except for ones having a near linear shape and constructed for higher average inlet pressure.

\section{Acknowledgments}

The research reported here in was supported by a grant from the National Science Centre, Poland (No. DEC-2016/23/N/ST8/01247).

\section{Nomenclature}

A surface area, $\mathrm{m}^{2}$

$G \quad$ mass flux, $\mathrm{kg} \cdot \mathrm{m}^{-2} \mathrm{~s}^{-1}$

I current, A

$\Delta U$ voltage drop, $\mathrm{V}$

$p_{\text {in }} \quad$ inlet pressure, $\mathrm{Pa}$

$q_{w}$ heat flux density, $\mathrm{W} \cdot \mathrm{m}^{-2}$

$R a$ arithmetic mean deviation of the roughness profile, $\mu \mathrm{m}$

$\mathrm{Sa}$ arithmetic mean height, $\mu \mathrm{m}$

$T$ temperature, $\mathrm{K}$

$x \quad$ distance from the minichannel inlet, $\mathrm{m}$ 


\section{Greek symbols}

$\alpha \quad$ heat transfer coefficient, $\mathrm{W} \cdot \mathrm{m}^{-2} \cdot \mathrm{K}^{-1}$

$\Delta T_{\text {sub }} \quad$ inlet liquid subcooling, $\mathrm{K}$

$\delta \quad$ thickness, depth, $\mathrm{m}$

$\lambda$ thermal conductivity, $\mathrm{W} \cdot \mathrm{m}^{-1} \mathrm{~K}^{-1}$

\section{Subscripts \\ $f \quad$ fluid \\ in at the inlet \\ out at the outlet \\ $p \quad$ plate}

\section{References}

1. C. Konishi, I. Mudawar, M. M. Hasan, Int. J. Heat Mass Transf. 65, 203-218 (2013)

2. F. T. Kanizawa, C. B. Tibirica, G. Ribatski, Int. J. Heat Mass Transf. 93, 566-583 (2016)

3. T. Bohdal, K. Widomska, M. Sikora, Arch. Thermodyn. 37(2), 41-69 (2016)

4. K. Strąk, M. Piasecka, B. Maciejewska, Int. J. Heat Mass Transf. 117, 375-387 (2018)

5. K. Strak, B. Maciejewska, M. Piasecka, EPJ Web of Conferences, 180, paper No. 02099 (2018)

6. B. Maciejewska, M. Piasecka, K. Strąk, XIth Int. Conf. Computational Heat, Mass and Momentum Transf., May 21-24 2018, Cracow, Poland (2018)

7. W. Depczyński, A. Piasecki, M. Piasecka, K. Strąk, E3S Web Conf. 19, paper No. 03012 (2017)

8. K. Strąk, M. Piasecka, D. Strąk, Mater. Res. Proc. 5, 154-159 (2018)

9. M. Piasecka, K. Strąk, B. Maciejewska, B. Grabas, J. Phys. Conf. Ser. 745, paper No. 032123 (2016)

10. Maciejewska, K. Strak, and M. Piasecka, Int. J. Numer. Methods Heat Fluid Flow 28(1), 206-219 (2018)

11. B. Maciejewska, K. Strąk, M. Piasecka, EPJ Web Conf. 114, paper No. 02068 (2016)

12. M. Piasecka, K. Strąk, B. Maciejewska, Heat Transf. Eng. 38(3), 332-346 (2017)

13. M. Piasecka and K. Strąk, EPJ Web Conf. 114, paper No. 02095 (2016)

14. M. Piasecka, K. Strąk, Heat Transf. Eng., 40(13-14) (2019), DOI:10.1080/01457632.2018.1457264

15. M. Piasecka, Int. J. Heat Mass Transf. 81, 114-121 (2014)

16. K. Strąk, M. Piasecka, Proc. XVIth Int. Conf. Heat Transfer and Renewable Sources of Energy, 253-260, Poland (2016)

17. W. Depczyński, J. Achiev. Mater. Manuf. Eng. 66(2), 7-72 (2014)

18. W. Depczyński, S. Spadło, P. Młynarczyk, E. Ziach, P. Hepner, Proc. 24th Int. Conf. Metall. Mater. Met. 2015, Poland (2015)

19. B. Grabas, Arch. Metall. Mater. 60(1), 33-39 (2015)

20. N. Radek, J. Konstanty, M. Scendo, Arch. Metall. Mater. 60, 2579-2584 (2015)

21. N. Radek, J. Orman, Ł., Scientific Basis of Modern Technologies: Experience and Prospects, 236-245 (2011)
22. R. Kaniowski, R. Pastuszko, Ł. Nowakowski, EPJ Web Conf. 143, paper No. 02049 (2017)

23. R. Kaniowski, R. Pastuszko, EPJ Web Conf. 143, paper No. 02050 (2017)

24. R. Kaniowski, R. Pastuszko, EPJ Web Conf. 180, paper No. 02041 (2018)

25. R. Pastuszko, M. E. Poniewski, M. Koziol, Heat Mass Transf., vol. 48(8),1367-1374 (2012)

26. R. Pastuszko, R Kaniowski, EPJ Web Conf. 25, paper No. 02019 (2012)

27. S. Błasiak, A. Zahorulko, Tribol. Int. 94, 126-137 (2016)

28. S. Błasiak, Int. J. Heat Mass Transf. 100, 78-88 (2016)

29. S. Błasiak, 2015, Int. J. Heat Mass Transf. 81, 90-102 (2015)

30. M. Piasecka, D. Michalski, K. Strąk, EPJ Web Conf. 114, paper No. 02094 (2016)

31. K. Strak, M. Piasecka, EPJ Web Conf. 180, paper No. 02098 (2018)

32. K. Strąk, M. Piasecka, EPJ Web Conf. 143, paper No 02116 (2017)

33. Calibration Certificate No. K1501035, Calibration Laboratory No. 2372, Accredited by Czech Accreditation Institute under ČSN EN ISO/IEC 17025:2005.

34. M. Piasecka, B. Maciejewska, Exp. Therm. Fluid Sci. 68, 459-467 (2015)

35. S. Hożejowska, R. Kaniowski, M. E. Poniewski, Exp. Therm. Fluid Sci. 78, 18-29 (2016)

36. B. Maciejewska, K. Strąk, M. Piasecka, Procedia Eng. 157, 82-88 (2016)

37. M. Piasecka, B. Maciejewska, Exp. Therm. Fluid Sci. 44, 23-33 (2013)

38. B. Maciejewska, M. Piasecka, Int. J. Heat Mass Transf. 107, 925-933 (2017)

39. M. Piasecka, K. Strąk, Trans. Inst. Fuid-Flow Mach. 128, 97-118 (2015)

40. M. Piasecka, K. Strąk, B.Grabas, Arch. Metall. Mater. 62(4), 1983-1990 (2017)

41. M. Piasecka, Int. J. Refrig. 56, 198-212 (2015) 